\begin{tabular}{l} 
SCIENCE \& TECHNOLOGY \\
Journal homepage: http://www.pertanika.upm.edu.my/ \\
\hline PERTANIKA
\end{tabular}

\title{
Palaeoecologic and Palaeoclimatic Inferences from Calcareous Nannofossils in Western Lobe Offshore, Niger Delta
}

\author{
Bamidele Samuel Oretade* and Che Aziz Ali \\ Department of Earth Sciences and Environment, Faculty of Science and Technology, Universiti Kebangsaan \\ Malaysia, 43600 UKM, Bangi, Malaysia
}

\begin{abstract}
In support of the ongoing temporal palaeoenvironment and palaeoclimatic reconstructions of the Neogene sediments, this study attempts to detail the paleo-proxies recovered from DEL-1 Well, western offshore Niger Delta. The standard smear slide method enabled the recovery of well-preserved calcareous nannofossils that depict early to mid-Miocene (NN4-NN5) sediments. The up-hole relationships between the nannofossil accumulation rate (NAR), the relative abundance of Discoaster and coccolith size of Reticulofenestra show step by step collapse of sea surface stability from early to middle Miocene. The lower horizons (8000-9460 ft) exhibit a low NAR, relatively high Discoaster abundance and relatively large Reticulofenestra size to suggest a deep thermocline and nutricline that characterise oligotrophic conditions in less warm-water induced climate. Conversely, upper horizons (5225-6550 ft) exhibit a high NAR, relatively low Discoaster abundance and relatively small Reticulofenestra size to suggest a shallow thermocline and nutricline that characterise eutrophic conditions in warm-water induced climate. The relative abundance of Helicosphaera carteri within the mid-NN5 suggests mesotrophic conditions within a stressed environment, with the possible occurrence of carbonate crash events. The combined parameters indicate gradual eutrophication and collapse of sea surface stability favouring nutrients and influx of terrestrial sediments in the ocean water as it progressed from early to middle Miocene. The abundance of the palaeo-proxies assemblages suggests

ARTICLE INFO

Article history:

Received: 06 June 2021

Accepted: 15 September 2021

Published: 04 January 2022

hyposaline waters in a neritic environment that prevailed during the warm climatic condition.
\end{abstract}

DOI: https://doi.org/10.47836/pjst.30.1.25

$\overline{\text { E-mail addresses: }}$

p95743@siswa.ukm.edu.my (Bamidele Samuel Oretade)

samtad@mail.com (Che Aziz Ali)

* Corresponding author
Keywords: Calcareous nannofossils, eutrophic, mesotrophic, Neogene sediments, oligotrophic, seasurface stratification 


\section{INTRODUCTION}

The need for examining deep wells drilled in the offshore portion of the Niger Delta are significantly becoming important to provide oceanic records linked with Gondwana breakup and evolution of the Atlantic Ocean to portrait marine conditions for the Gulf of Guinea relative to another proven world oceanic and palaeoceanographic evolution (Guerra et al., 2011; Adegoke et al., 2017). Notably, recent advancements in exploring coastal to deep waters have aided modern understanding of the use of micropalaeontological studies in deciphering ancient to modern oceanographic evolution, perhaps enhancing hydrocarbon exploration. In addition, several researchers have highlighted the pragmatic approach to nannofossil biostratigraphy over the years (Hay et al., 1967; Erba, 2004; Erba, 2006; Zachos et al., 2004; Brown, 2005; Raffi et al., 2006; Vulc \& Silye, 2005) in examining global fields/basins for nannofloral existence and biodiversity in palaeoecological and palaeoceanographical reconstructions.

In the Niger Delta, foundational reports of Oyebamiji (1997) and Fadiya (1999) on calcareous nannofossil were reported for their age determination, occurrences, and distribution patterns to aid exploration processes. Recent documented studies (Ojo et al., 2009; Fadiya \& Salami, 2012; Obaje \& Okosun, 2013; Ajayi \& Okosun, 2014; Sanuade, 2014; Adegoke et al., 2017; Ola, 2018) on the Neogene nannoplankton in the Niger delta highlighted their phylogenetic and paleobathymetric reconstructions, with limitations to their enigmatic palaeoecological and biogeochemical imprints on the Niger Delta palaeobiogeography (Adegoke et al., 2017). However, calcareous nannofossils are geographically distributed in present ocean columns, from coastal areas to open ocean settings and constitute a large part of marine phytoplanktonic communities along with diatoms, dinoflagellates, and cyanobacteria (Erba, 2006). The use of nannofossils in Neogene palaeoceanographic reconstruction seems challenging due to dearth, ecologically restriction, vulnerability to diagenesis and ongoing extinction to most species as a result of extreme nature and environmental changes (Erba, 2006). Conversely, the authors believe that these challenges are very useful in exploring the complex interplay of ocean chemistry, productivity, climate, and tectonics of ocean water.

The factors mentioned above are considered important for the geographical and vertical distribution of oceanic phytoplankton. Furthermore, these are known to differ between taxa and their respective responses to surface water properties such as light, temperature, salinity, turbidity, and nutrient content (McIntyre \& Bé, 1967; Imai et al., 2015), thereby highlighting their importance in palaeoecologic and palaeoceanographic reconstructions. However, this study curiously explores the use of nannofossil accumulation rate (NAR; Flores \& Sierro, 1997) and the relationship between ecologic proxies (Discoaster, coccolith size of Reticulofenestra and Helicosphaera species) to construe the palaeoceanographic conditions astronomically driven by climatic cycles during sedimentation within the Gulf of Guinea. 
Notably, some studies showed evidence of fluctuating surface water properties with progressive collapse of sea surface stability across different oceans' columns (Zhang et al., 2007; Farida et al., 2012; Imai et al., 2015). Thus, indicate substitution in prevalence and gradual collapse regionally of thermocline and nutricline for prevailing mesotrophic/ eutrophic conditions. These are most often responsible for vertical occurrence and distribution of calcareous nannoplankton along with ocean columns (Sato \& Chionobu, 2009). Therefore, there is a need to explore local nannofloral response(s) to these changes in ocean chemistry that are often accompanied by dynamic factors. Such as atmosphericoceanic $\mathrm{CO}_{2}$ exchange, primary production, and fluxes of biogenic and inorganic particles, which are responsible for either/both fluxes in surface water productivity and carbonate production that could lead to eutrophication or carbonate crash events (Fadiya \& Salami, 2012). In this study, the presence of calcareous nannoplankton in DEL-1 Well, offshore Niger Delta will be analysed for their abundance and distribution patterns. With the goals to (1) deduce the stratigraphical age of the well section (2) succinctly examine the relationships between the NAR and ecologic nannofloras to construe the palaeoecologic and palaeoenvironmental inferences, and (3) interpret marine developmental changes to reconstruct palaeoceanographic condition of the studied section.

\section{Geological Setting of the Western Detachment Fold Zone}

The field under investigation is located within the western detachment fold zone (DFZ), a subdivision of the offshore depositional belt marginally positioned to the border of the southwestern Niger Delta (Figure 1). The DFZ elongated southward towards the east of the basin. The zone is mapped within the more deep-water region of the Niger Delta, known as the toe of the delta (Bilotti \& Shaw, 2005). It comprises numerous thrust faults and thrust-associated folds (Corredor et al., 2005), which constituted some fields within the area that benefited from the structural traps formed by contractional fold. The studied field is classed under the fault-bend fold of the subdivision of the contractional part of the deep-water (Connors et al. 1998; Corredor et al., 2005) in the Niger Delta. The DFZ is an intermediate zone between the inner and outer fold and thrust belts characterised by the province of little or no. Distortion interspersed with broad detachment anticlines accommodates relatively small amounts of shortening aided by faults and folds" (Bilotti et al., 2005). The Opuama Canyon's encroachment on the north-western margin of the delta (Figure 1) created a great influence on the deposited sediment packages in the DFZ area (Ozumba, 2018). The oldest deposited sediments in the western DFZ were dated late Oligocene, while the sedimentation processes were mainly dominated by marine facies, deposited beneath the presented day delta front consisting of Oligocene and Miocene delta fronts (Ozumba, 2018). The deposition of the Akata facies took place in the Oligocene, while the onset deposition of the paralic lithofacies making the Agbada Formation started in the early Miocene age onwards (Figure 2; Ozumba, 2018). 


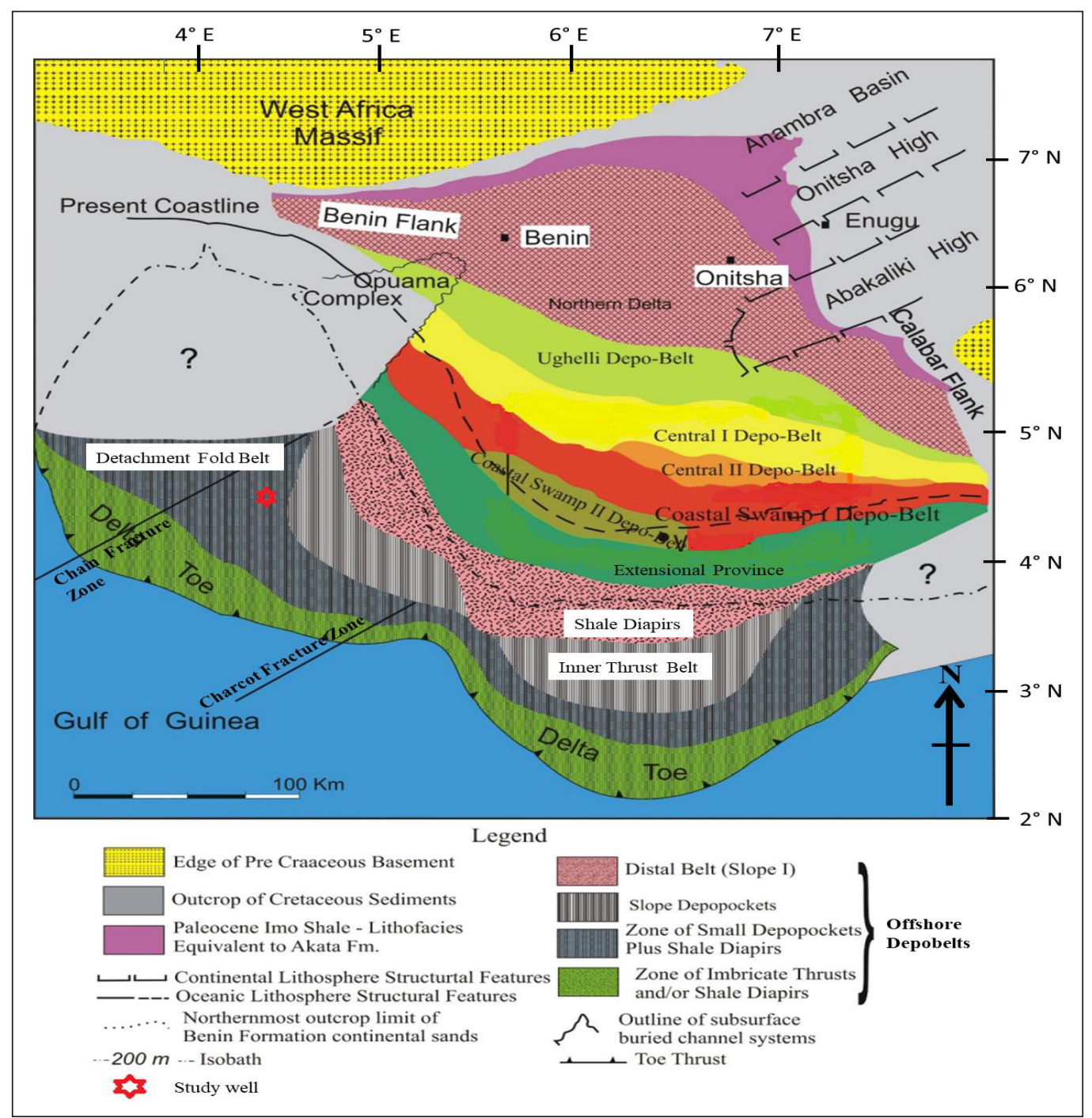

Figure 1. The regional map of the Niger Delta, showing the distribution of main structural elements and depobelts, highlighted in red the study well (modified after Doust and Omatsola, 1990)

The Akata Formation is the basalmost deposit and the major hydrocarbon source rock in the Niger Delta (Reijers, 2011; Ozumba, 2018). It is characteristically made up of marine shale (Figure 2). The Agbada Formation serves as the reservoir unit, and it is the exploration target for conventional hydrocarbon in the Niger Delta. It is lithologically composed of interbeds of sand/sandstone, shale and other constituents often composited as heteroliths in almost equal proportion (Magbagbeoloa \& Willis, 2007; Reijers, 2011). Finally, the youngest lithounit in the basin is the continental deposit of the Benin Formation that is essentially composed of massive sandstone with negligible shale lamina and lignitic infringements (Reijers, 2011; Momta \& Odigi, 2014). 


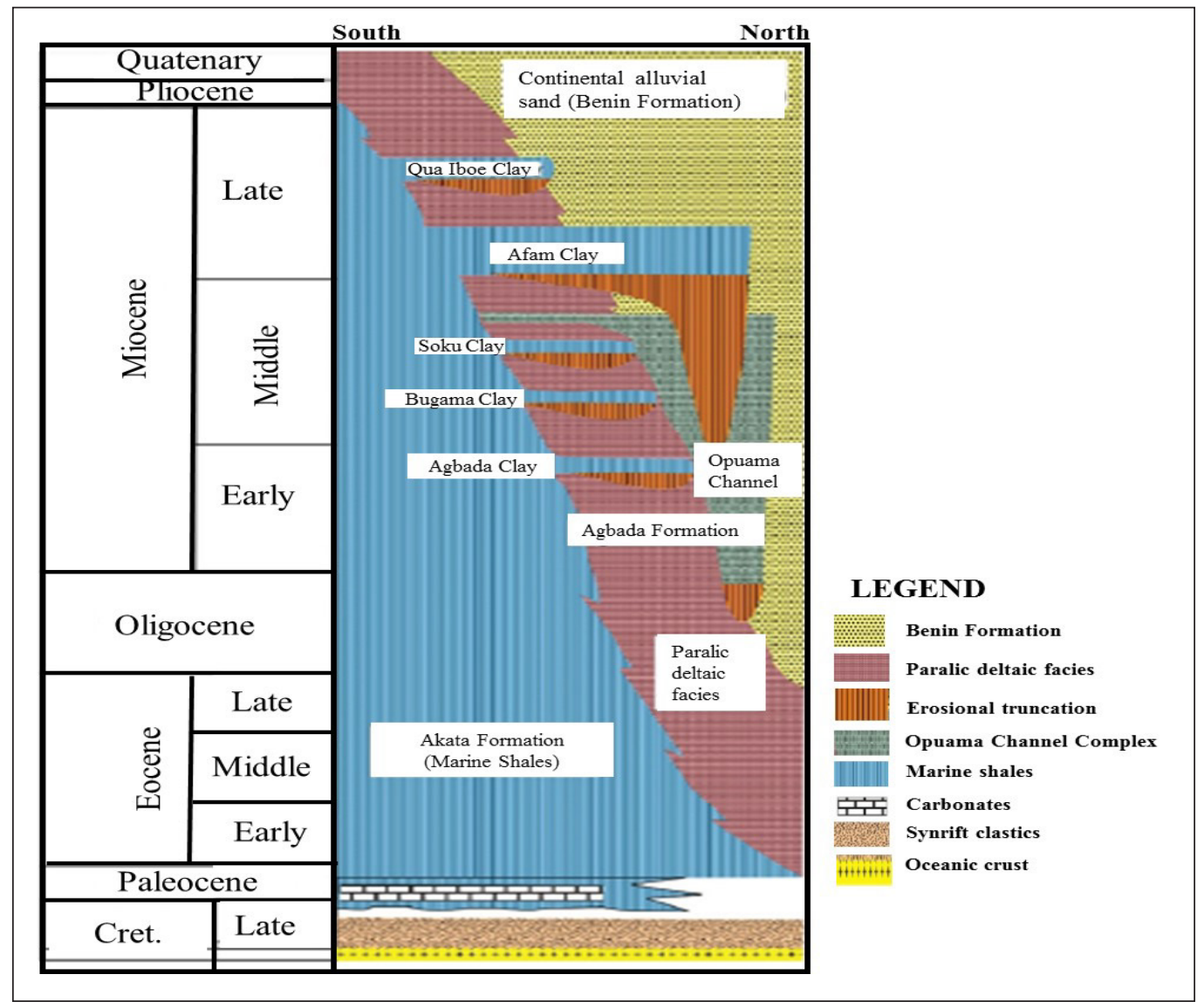

Figure 2. Chrono-stratigraphic diagram showing the three Formations of the Niger Delta Modified after Doust and Omatsola (1990)

\section{MATERIALS AND METHODS OF STUDY}

The lithologic description of each sample was carried out using a stereo-binocular microscope for its constituents and proportions. A graphic sediment log for the well section was created using SedLog 3.1 software (Zervas et al., 2009) to compliment the lithologic description of the samples examined with the interpreted lithologic log from the gamma-ray and resistivity logs. Biostratigraphically, Bown and Young (1998) standard strewn-slide technique was used to process and analyse calcareous nannoplankton in deciphering their biostratigraphical significance and events.

Five grams of each sample was carefully selected from the 25 composite ditch cuttings recovered within a section (4600 - $9460 \mathrm{ft}$ ) of DEL-1 Well. Each weighed sample was put on a clean white sheet of paper, folded, and gently crushed because of the fragile nature of nannofossils using a pestle. The crushed materials were dispersed in distilled water inside a glass. Vials were stirred with a stirring rod, after which they were decanted into another 
glass tube. Next, the decanted suspensions were pipetted with disposable pipettes onto each $22 \times 40 \mathrm{~mm}$ coverslips placed on a regulated hot plate to gently dry at a temperature of about $50-60^{\circ} \mathrm{C}$. Then, the coverslips were mounted on the labelled glass slides using two drops of Norland optical adhesive mounting medium (Refractive index $=1.56$ ) and cured under ultraviolet light for forty-five minutes. Finally, the prepared slides were examined for their calcareous nannofossils' content under a high-powered Olympus light microscope in cross-polarized and transmitted light in three traverses.

Numbers of different species found were recorded to get their known abundance and diversity. Detailed identification of the assemblages and description is based on previous works (Martini, 1971, Backman, 1984; Perch-Nielsen, 1985) and other relevant texts mentioned in the discussion section. The calcareous nannofossil bio horizons were deduced based on first occurrence (FO), last occurrence (LO), first consistent occurrence (FCO), last consistent occurrence (LCO) and paracme ending (PE) of marker species in accordance with the zonation scheme of Martini (1971). The chronostratigraphic subdivisions were correlated with the geological time scale (GTS) sensu (Gradstein et al., 2020). Photographs of the forms were taken using an OLYMPUS CX31PF binocular microscope with a camera attached.

Estimating the absolute abundance of nannofossils was carried out by counting in random visual fields, while the total abundance of nannofossils (Helicosphaera, Reticulofenestra and Discoaster inclusive) using Equation 1 according to Flores and Sierro (1997).

$$
\mathrm{N}=\mathrm{n} * \mathrm{R}^{2} * \mathrm{~V} * \mathrm{r}^{2} * \mathrm{~g}^{-1} * \mathrm{v}^{-1}
$$

The "N" represents a number of nannofossils per gram of dry sediments; " $n$ " represents the number of nannofossils in a random scanned area; "R" represents the radius of Petri disk; $\mathrm{V}$ represents the volume of water added to the dry sediment in the beaker; "r" represents the radius of the visible field of study; "g" represents the weighted dry sediments, and lastly "v" represents a volume of mixture pipette. Therefore, the Nannofossil Accumulation Rate (NAR) was calculated as accounted by Flores and Sierro (1997) as in Equation 2:

$$
\mathrm{NAR}=\mathrm{N} * \mathrm{~d} * \mathrm{~S}
$$

Where NAR (nannofossil $\left.* \mathrm{~cm}^{-2} * \mathrm{ky}^{-1}\right)$; $\mathrm{d}$ is the dry density of the sample $\left(\mathrm{g} * \mathrm{~cm}^{-3}\right)$, and $\mathrm{S}$ is the linear sedimentation rate $\left(\mathrm{cm}^{*} \mathrm{ky}^{-1}\right)$.

\section{RESULTS}

\section{Sedimentological Overview of DEL-1 Well}

The ditch cuttings analysed span the interval of 4500 to $9460 \mathrm{ft}$ that showed a good variation of lithic units to characterise dominant clastic sedimentation. Lithological observations and descriptions of the ditch cuttings from the DEL-1 Well show the well predominantly 
penetrated sandstones, shales, silts and paralic sandstone-shale intercalations, which essentially constitute the Agbada Formation (Figure 3). A critical assessment of the studied litho-section revealed the differences between the upper transitional paralic (4500-6750 $\mathrm{ft}$ ) and lower paralic (6750-9460 ft) horizons of the Agbada Formation.

The lower horizons exhibit paralic thick shale intervals with packets of sandstone beds to be named the lower paralic horizons (Figure 3). The shales are thickly bedded with thickness ranging from 100 to $450 \mathrm{ft}$ and pale grey to greyish. The sandstones are brownish to yellowish-white, dominantly medium-grained, and angular to subangular. However, the shale became grey while the sandstone showed prominent yellowish-white colouration up-hole. The grains are coarser and subangular within the depth interval 7000-7500 ft. On the gamma-ray log signature of the DEL-1 Well, the sandstone is characterised by dominant coarsening upward unit (with typical funnel-shaped log motif) with sand percentages varying from $20-46 \%$, the log motifs suggest delta front, river mouth bar sub-facies environment and crevasse splay sub-facies environment (Selley, 1985). However, the shale-sand heterolithic subunit consists of $20 \%$ grains of sand and exhibits slightly serrated coarsening log motifs (7000-7500 ft) upward; this can be interpreted as an intertidal to the tidal sub-facies environment. Conversely, the sandstones in the upper unit of this interval are brownish to off-white, medium to fine-grained and subangular to subrounded (Figure 3).

The upper horizons are interpreted as an upper transitional paralic sequence, characterised by a preponderance of sandstone with interbeds of shale and silts (Figure 3 ). The thick sandstone beds vary in thickness from 30 to $480 \mathrm{ft}$. The sandstones are generally medium to fine-grained but occasionally coarse-grained at the upper section of the horizon. However, the sandstone units are yellowish-brown to off white, subangular to subrounded and poorly to moderately sorted. The log analysis shows the gamma-ray log motif for the sandstone are serrated blocky-shaped units with 75-90\% sands and could be interpreted to a distributary channel subfacies to channel-fill or submarine canyon-fill subfacies environment (Selley, 1985). The shales are dark grey, platy to occasionally blocky and moderately hard. The silts facies are fine-grained, off-white to brownish-white in colour. The shale exhibited a shelf mud deposition in shallow marine settings.

\section{Recognised Calcareous Nannofossils Bioevents}

The detailed analysis of the ditch-cuttings revealed low to moderate species abundance and richness of calcareous nannoplankton over most horizons of the well section. These are evident when some samples yielded a countable taxa abundance and evenness while few samples were barren of calcareous nannoplankton. Forty-seven species from fifteen genera were recognised and dominated by placoliths, helicoliths and nannoliths (Figure 4), while some photomicrographs are presented in Figure 5. The well is inferred to penetrate Middle 


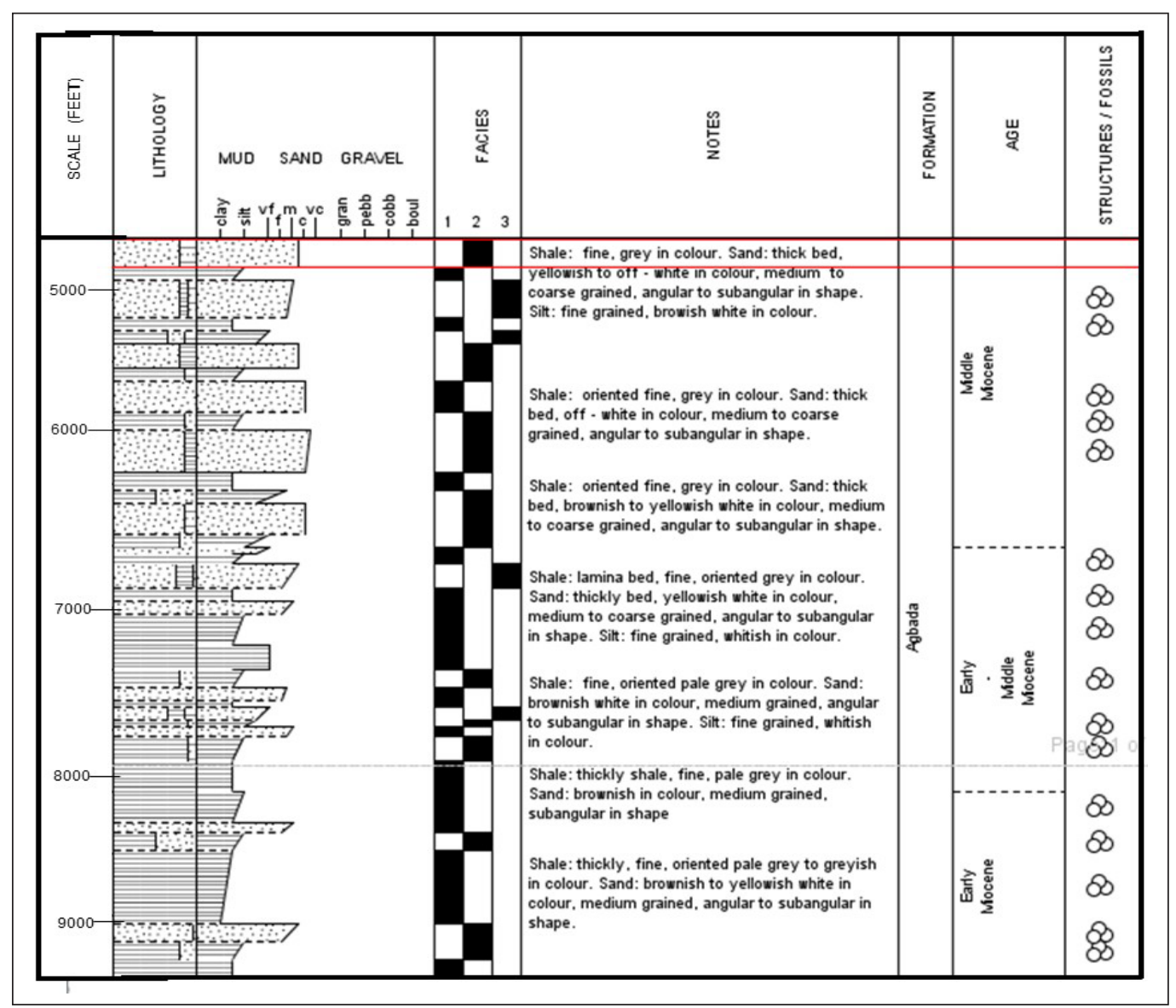

Figure 3. Harmonised down-hole profiling of sedimentological sequences of DEL-1 Well, consisting of the lithology description and lithofacies assemblages

Note. facies assemblages' representation mono-facies, two facies, three facies

to Early Miocene zones (NN5-NN4), while several important calcareous nannofossil bioevents are recorded over the analysed well section (Figure 4) and are described below.

\section{Nannoplanktons Zone \\ : Non-diagnostic \\ Stratigraphic Interval \\ Age

$$
\begin{aligned}
& \text { : } 9025-9460 \mathrm{ft} \\
& \text { : Early Miocene }
\end{aligned}
$$

The top of the interval is marked by the probable LDO of Sphenolithus heteromorphus at $9025 \mathrm{ft}$ (Figure 4). This interval is marked by moderate abundance and diversity of nannofossils. The abundance/richness peak recorded over the interval 9000-9075 ft is suggestive of a condensed section, which is suspected to be of a post $17.4 \mathrm{Ma}$. The age is uncertain due to the non-recovery of marker species in this interval. The nonrecovery of Sphenolithus belemnos used globally to define the NN3 Zone of Martini (1971) supports the evidence that the well did not penetrate sequences older than NN4. 
In addition, although species of Triquetrorhabdulus were recorded at the upper interval as a key assemblage species for NN2, Triquetrorhabdulus carinatus was not observed. The calcareous nannofossils recovered within this interval are Calcidiscus leptoporus, Coccolithus pelagicus, Cyclicargolithus floridanus, Discoaster deflandrei, Discoaster druggii, Discoaster spp. (6 rays), Helicosphaera ampliaperta, Helicosphaera carteri, Helicosphaera obliqua, Helicosphaera spp., Sphenolithus moriformis and Sphenolithus spp. The base of this interval is tentatively placed at the lowest sample analysed (Figure 4).

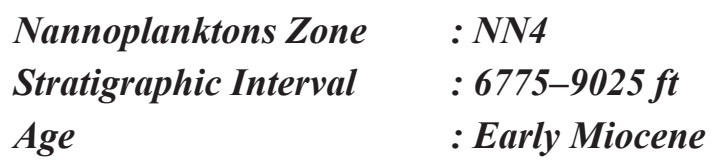

The top of this interval is marked with probable LO of Helicosphaera ampliaperta (15.6 Ma.) and PE of Sphenolithus heteromorphus at depth $6775 \mathrm{ft}$ (Figure 4). The base of this interval is marked by the probable FO of Sphenolithus heteromorphus and FCO of Helicosphaera ampliaperta at $9025 \mathrm{ft}$ (Figure 4). This interval is marked by increased abundance and diversity of nannofossils with respective abundance or richness peaks recorded within the depth interval $6750-6850 \mathrm{ft}, 8200-8350 \mathrm{ft}$ and $8950-9100 \mathrm{ft}$ to suggest candidate condensed sections of Haq et al. (1988) based on their stratigraphic positioning. The age of the condensed basal section (8950-9100 ft.) could not be dated precisely due to the absence of distinctive marker species; however, the probable FCO of Helicosphaera ampliaperta characterise the candidate indication. The dominant occurrence of Helicosphaera ampliaperta over the enormous abundances of Sphenolithus heteromorphus, Sphenolithus moriformis, and Helicosphaera carteri within the depth interval 8200-8350 $\mathrm{ft}$ suggests that this section of the well falls within the basal biohorizon of the NN4 Zone (Young, 1998). Thus, suggest a nannofossil bioevent relative to the 17.4 Ma. (Figure 4). The PE of Helicosphaera ampliaperta (dated 15.6 Ma.) within the depth interval $67506850 \mathrm{ft}$ could characterise the condensed upper section of this zone. However, the recovery of the following calcareous nannofossils: Braarudosphaera bigelowii, Calcidiscus leptoporus, Coccolithus pelagicus, Calcidiscus macintyrei, Cyclicargolithus floridanus, Dictyococcites productus, Discoaster deflandrei, Helicosphaera ampliaperta, Pontosphaera discopora, among other taxa, characterise the NN4 nannofossil zone.

$\begin{array}{ll}\text { Nannoplankton Zone } & : N N 5 \\ \text { Stratigraphic Interval } & : 5500-6775 \mathrm{ft} \\ \text { Age } & : \text { Middle Miocene }\end{array}$

The top of the interval is marked by the LO of Sphenolithus heteromorphus at 5500 $\mathrm{ft}$ (Figure 4). The base of the nannoplankton zone is placed at $6775 \mathrm{ft}$, the next sample above the LO of Helicosphaera ampliaperta and PE of Sphenolithus heteromorphus. A moderate abundance of nannofossils characterises this interval. However, the peaks in 


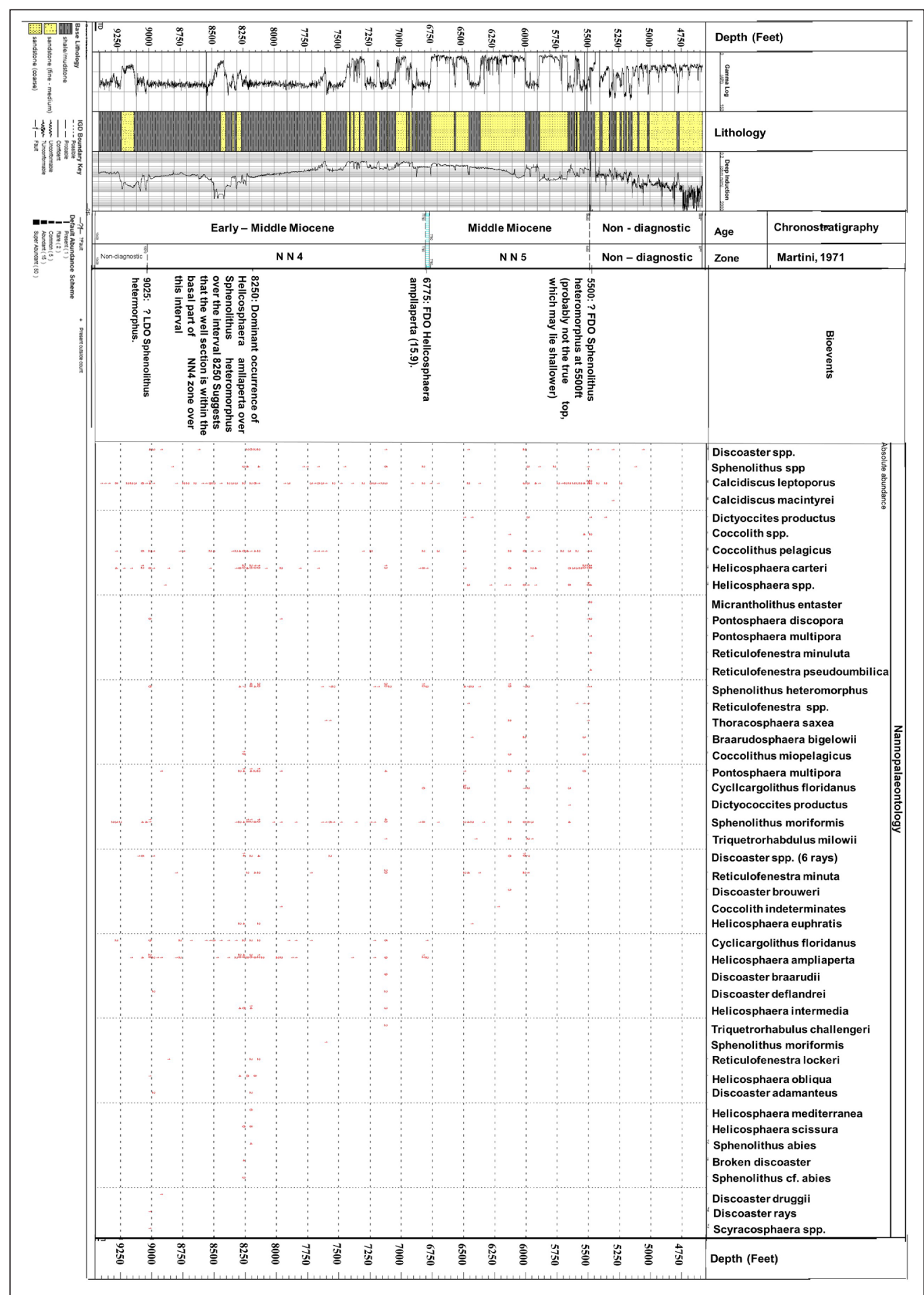

Figure 4. Stratigraphic summation and distribution chart of calcareous nannofossils of DEL-1 Well, with the corresponding gamma-ray $\log$ and interpreted lithologic facies 


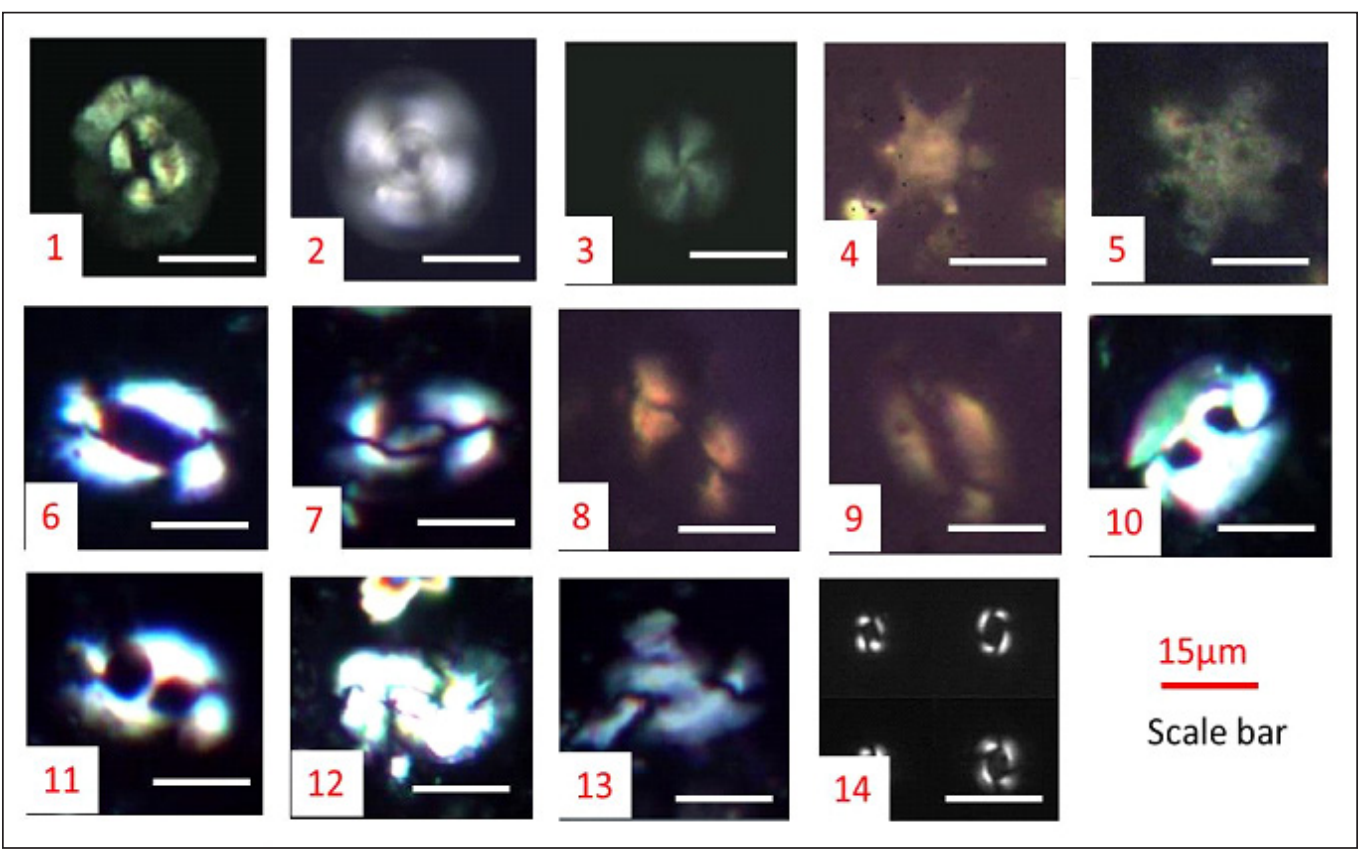

Figure 5. Some nannofloral species recouped from the studied well, including (1) Coccoliths pelagicus (Wallich, 1877; Schiller, 1930). (2) Calcidiscus macintyrei (Bukry \& Bramlette, 1969). (3) Calcidiscus leptoporus (Murray \& Blackman, 1898; Loeblich \& Tappan, 1978). (4) Discoaster spp. (6 rays) (Bown \& Dunkley, 2012). (5) Discoaster druggii (Bramlette \& Wilcoxon, 1967). (6) Helicosphaera ampliaperta (Bramlette \& Wilcoxon, 1967). (7) Helicosphaera euphratis (Haq, 1966). (8) Helicosphaera carteri (Wallich, 1877; Kamptner, 1954). (9) Helicosphaera scissura (Muller, 1981). (10) Helicosphaera oblique (Bramlette \& Wilcoxon, 1967). (11) Helicosphaera mediterranea (Muller, 1981). (12) Helicosphaera intermedia (Martini, 1965). (13) Helicosphaera spp (Bown \& Dunkley, 2012). (14) Reticulofenestra minuta (Roth, 1970).

abundance and species count recorded within the stratigraphic interval 5480-5580 ft are probably relics of a condensed section (maximum Flooding Surface) that could be related to the 15.0 Ma. of Haq et al. (1988). The associated calcareous nannofossils recovered within this interval are Braarudosphaera bigelowii, Calcidiscus leptoporus, Coccolithus pelagicus, Calcidiscus macintyrei, Cyclicargolithus floridanus, Dictyococcites productus, Discoaster sanmiguelensis, Discoaster spp. (6 rays), Helicosphaera carteri, Helicosphaera spp., Micrantholithus entaster Pontosphaera discopora, Pontosphaera multipora, and Triquetrorhabdulus milowii.

\section{Nannoplankton Zone $\quad$ : Non-diagnostic \\ Stratigraphic Interval $\quad: 4500-5500 \mathrm{ft}$. \\ Age \\ : Non-diagnostic}

This interval is characterised by scanty occurrences of long-ranging and non-age diagnostic nannoplankton (Figure 4). The nannoplankton species presented here are of sparing distribution within the interval, such as Calcidiscus leptoporus, Calcidiscus macintyrei, Dictyoccocites productus and Discoaster spp. 


\section{Succession of Bioevents}

Discoaster Bioevents. Eight distinguished species of Discoasters were identified in this study (Figure 4), which belong to the family Discoasteraceae with the features of rayed nannoliths. The generally small size $(\leq 20 \mu \mathrm{m})$ of these species made them extremely useful for Tertiary bioevents, evident in their short life span and fast extinction (Perch-Nielsen, 1989; Bown, 1999). Discoasters are phytoplankton, notably from their assemblages to reflect microorganism productivity within their niche (Flores \& Sierro, 1997; Flores et al., 2005; Sato \& Chiyonobu, 2009). The general trend within the studied interval exhibits a relatively low abundance of Discoasters showing cyclic distribution up-hole with considerable fluctuating occurrences along some horizons (Figure 4). Discoaster species were abundant within the depth interval $8980-9160 \mathrm{ft}$, with the highest relative abundance exceeding $18 \%$ was recorded at $9040 \mathrm{ft}$.

At depth interval $8200-8320 \mathrm{ft}$, the relative abundance exceeding $14 \%$ was recorded at depth $8320 \mathrm{ft}$ displaying a gradual decrease in abundance up-hole within the horizons. A sparse occurrence was recorded $6140-8140 \mathrm{ft}$ with an abrupt increase in abundance at depth $7180 \mathrm{ft}$ horizons within the depth interval 5920-6100 ft showed a relative abundance of the species with exceeding $10 \%$ recorded at depth $6010 \mathrm{ft}$. Low relative abundance of Discoaster species (typically less than 2\%) was recorded at depth interval 5060-5480 ft. to cap its distribution within the studied succession (Figure 4). However, relative occurrences of Discoaster species have been documented and interpreted as warm oligotrophic water species (Flores \& Sierro, 1987; Aubry, 1992; Flores et al., 2005; Sato \& Chiyonobu, 2009; Obaje \& Okosun, 2013). Thus, indicate their susceptibility to prevailing surface water stability within the deep section of the well. It suggests an ecological imprint of a lower photic zone (Sato \& Chiyonobu, 2009; Obaje \& Okosun, 2013).

Helicosphaera Bioevents. The qualitative plot for the studied horizons recorded two major Helicosphaera bioevents relative to their occurrence, abundance trend, and size distribution pattern (Figure 4). The measured Helicosphaera coccolith size ranged from 6 to $8 \mu \mathrm{m}$ with modal size at $7 \mu \mathrm{m}$; the maximum size was recorded at depth $8290 \mathrm{ft}$, while the minimum size was $5620 \mathrm{ft}$. The occurrence pattern for Helicosphaera assemblages shows progressive presence across the horizons, as their abundance is observed in two subdivisions as upper and lower horizons. The lower horizons (8170-9460 ft) show a gradual increase in abundance with continuous occurrence trailing up-hole. The taxa have a more distinct distribution trend that signals ecostratigraphic gains, suggesting a conducive and stable environment favouring an increase in occurrence and abundance with associated species. The assemblage in the lower horizon has its highest relative abundance exceeding 38\% recorded at depth $9130 \mathrm{ft}$ followed with abrupt decrease. The relative maximum abundance 
(90\%) was reached at depth $8260 \mathrm{ft}$., coincides with the condensed section dated 17.4 Ma. that precede the abrupt decrease in their abundance.

The upper horizons (4600-8140 ft) show low to average (to total number) abundance and discontinuous occurrences with some high abundance $20 \%$ and $26 \%$ at depth intervals 7150 and $6820 \mathrm{ft}$., respectively. The Helicosphaera carteri is dominant within depth interval 5480-5620 $\mathrm{ft}$ to show a progressive occurrence of the taxa with the highest relative abundance of $30 \%$ at depth $5480 \mathrm{ft}$. However, depth interval 4600-5480 ft shows a relative barren section within the upper horizon to cap the bioevents of Helicosphaera coccolith in the studied well. Conversely, the abundance pattern of the Helicosphaera species within the studied succession supports the putative advantage for the species to be characterised as a diagenetic-resistant species, based on its abundance and widespread elemental factor among the nannofloras (Young, 1990; Gartner, 1992; Flores et al., 2005; Kameo at al., 2010).

NAR Frequency and Changes in Reticulofenestra coccolith Size. The bioevents of Reticulofenestra species in studied sediments generally recorded low occurrences with fluctuating differences with the NAR (Figure 6). The distinguished species show relatively low recording of $0.9-12.0 \times 10^{9} \mathrm{specimens} / \mathrm{cm}^{2} / \mathrm{ky}$ across the entire studied section, with depth interval $6520 \mathrm{ft}$. having the maximum recording. Low frequencies were recorded down-hole within depth interval $8170 \mathrm{ft}$. to $9460 \mathrm{ft}$ with a variance of $0.9-3.9 \times 10^{9}$ specimens $/ \mathrm{cm}^{2} / \mathrm{ky}$. An increase in NAR has observed up-hole at depth interval $8140 \mathrm{ft}$, with fluctuations ranging 4.0-12.0 $\times 10^{9}$ specimens $/ \mathrm{cm}^{2} / \mathrm{ky}$. A distinct increase in the NAR was recorded within depth interval $6400 \mathrm{ft}$. to $7030 \mathrm{ft}$ with a record of $11.9 \times 10^{9}$ specimens/ $\mathrm{cm}^{2} / \mathrm{ky}$, followed by large fluctuations over the range of 4.0-9.0 $\times 10^{9} \mathrm{specimens} / \mathrm{cm}^{2} / \mathrm{ky}$ to the top horizon at $5300 \mathrm{ft}$. In summary, the NAR generally exhibits a gradual increase at the upper horizons of the studied well (Figure 6).

This study put together the modal size of Reticulofenestra coccoliths across the stratigraphic changes. The majority of Reticulofenestra coccoliths are of the diameter ranging between 6 and $10 \mu \mathrm{m}$ in a gradual increase pattern in the lower part of the studied interval 8500-9450 ft. An abrupt decrease in modal Reticulofenestra size to 7-8 $\mu \mathrm{m}$ was identified at $8140-8460 \mathrm{ft}$. It was followed by a further decrease in size $(3-4 \mu \mathrm{m})$ up to depth $7150 \mathrm{ft}$, where the modal size increased to $6 \mu \mathrm{m}$. However, the modal size of Reticulofenestra coccoliths gradually decreases with a value ranging $2-4 \mu \mathrm{m}$, from a depth of $5480 \mathrm{ft}$ to $6490 \mathrm{ft}$ for the bimodal size distribution. It is specifically critical within the range 6370-6490 ft. Most specimens were found to exhibit a bimodal size of 2-3 or 3-4 $\mu \mathrm{m}$ from 5480 to $5650 \mathrm{ft}$ and followed by an abrupt absence of Reticulofenestra coccoliths within depth interval 4500 to $5480 \mathrm{ft}$. Reticulofenestra coccoliths reached the 
maximum sizes of $9-10 \mu \mathrm{m}$ at $8860 \mathrm{ft}$ and the minimum sizes of $2-3 \mu \mathrm{m}$ at $5490 \mathrm{ft}$. The summarized results indicate an overall gradual upward decrease in modal and maximum sizes of Reticulofenestra coccoliths throughout the studied interval.

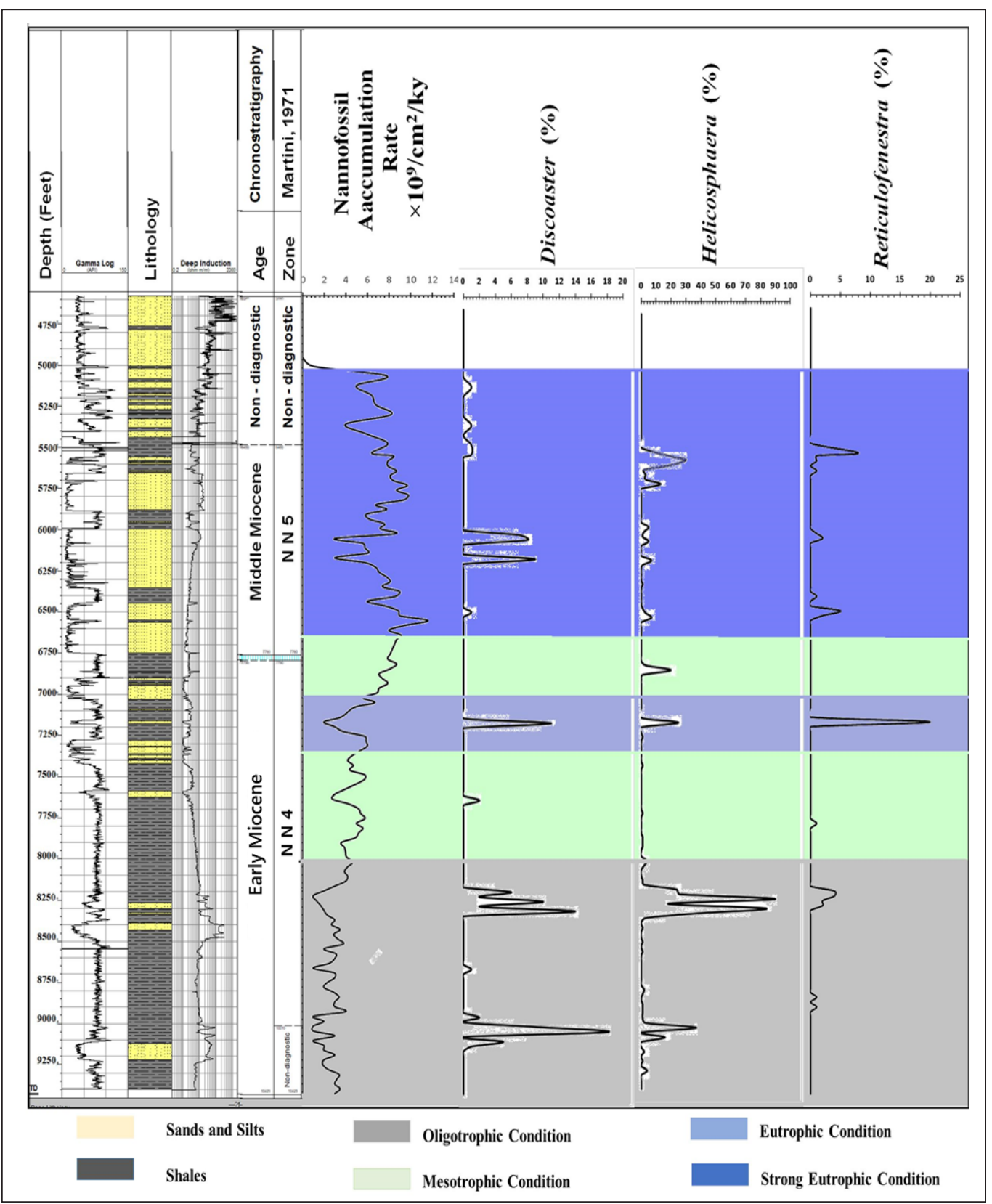

Figure 6. A comparison chart for nannofossil accumulation rate, recouped relative abundances of Discoaster, Helicosphaera and Reticulofenestra species, deciphering the environment and water condition along with the stratigraphic profile. Plotted with the gamma-ray log and interpreted lithological profile. 


\section{DISCUSSION}

Eco-stratigraphic deductions were made from integrating some selected calcareous nannoplanktons with the nannofossil accumulation rate tool. The relationship among the NAR, the relative abundance of Discoaster, Helicosphaera bioevents and Reticulofenestra coccolith size distribution (Figures 4 and 6) permits quantitative abundances and fluxes of nannofossils along with the stratigraphic sequences for a better understanding of the sea surface temperature and nutrient variability in palaeoceanographic reconstruction. In line with this concept, the following perspectives were made from the studied sediments: (a) $8500-9450 \mathrm{ft}$ (early Miocene 17.4Ma): This horizon is characterised by the low frequency of NAR, the relative abundance of Discoaster spp., and abundant large Reticulofenestra coccoliths recorded (Figure 6), suggesting enhanced oligotrophic conditions with a stable sea surface mechanism within the purported depth (Imai et al., 2015) (b) 7780-8500 ft (early Miocene): An increase in NAR, an abrupt increase of Discoaster abundance, and decreased modal size of Reticulofenestra coccoliths (i.e., continuous decrease in size upward the interval) were recorded for this interval (Figure 5). These characteristics can be suggested as indicative of higher nutrient content compared to the preceding interval (c) 6490-7780 ft (middle Miocene 15.9Ma): This period is characterised by a steady increase in NAR, a diminution in the abundance of both Discoaster spp. and a large size of Reticulofenestra coccoliths. Also present is a lone abundance of small size Reticulofenestra coccoliths within this interval. These combined factors were interpreted as an indicator of increasingly eutrophic conditions predominant at this interval, with the stepwise collapse in sea surface stability favouring nutrient gained (d) 4500-6490 ft. (middle Miocene 15.0Ma): A steady NAR increase, a barely very low abundance of Discoaster spp. and predominantly abundance of small Reticulofenestra coccoliths were recorded within this interval (Figure 5) to highlight eutrophic conditions. Consideration was taken on the frequency of bimodal size distribution and reduction in maximum size of Reticulofenestra coccoliths within this interval, indicative of strong eutrophication at the sea surface.

However, the above local interpretation of the studied succession can be extrapolated central to theoretical facts on biogeochemical and ecological components of the proxies that reflect the temperature and nutrient changes along the ocean column (Sato \& Chiyonobu, 2009; Imai et al., 2015). It could be explicitly summarised in the following two major statements. First, horizons characterised with low frequency of NAR and the presence of abundant large Reticulofenestra coccoliths with a high relative abundance of Discoaster spp., suggest the development of deep fall in thermocline and nutricline that symptomatically induce an oligotrophic condition prevailing at the sea surface (Flores et al., 1995; Farinaciari et al., 2000; Sato \& Chiyonobu 2009). Second, horizons characterised with a high frequency of NAR and abundant small Reticulofenestra coccoliths with the relative abundance of Discoaster spp. suggest the dominance of thermocline and nutricline 
at the sea surface, eliciting evident of prevailing eutrophic conditions at the sea surface (Flores et al., 1995; Imai et al., 2015).

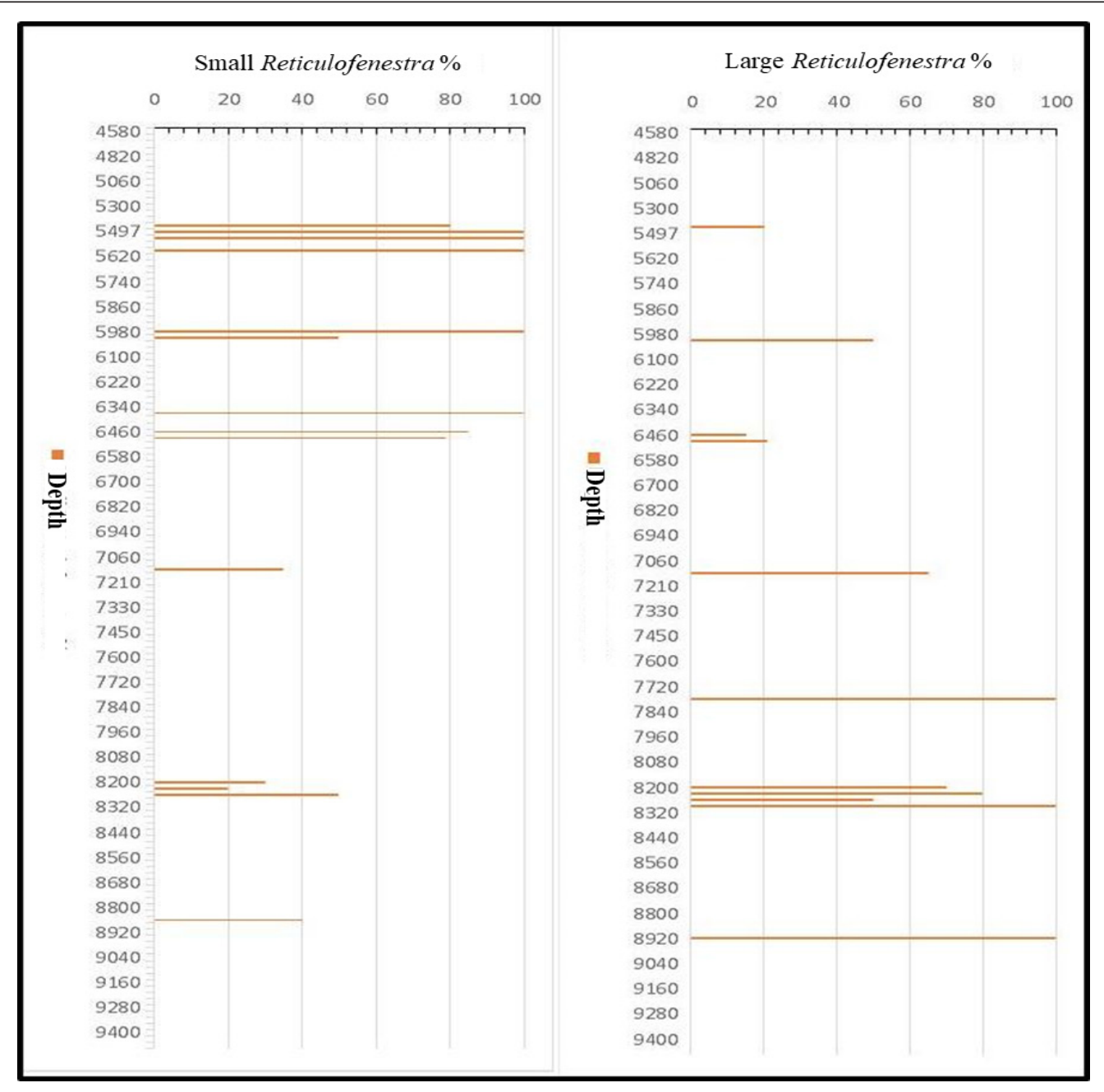

Figure 7. Stratigraphic percentile distribution of coccolith size distribution of Reticulofenestra in DEL-1 Well. Small size Reticulofenestra increases up-hole while large size Reticulofenestra decreases up-hole.

\section{Miocene Palaeoceanographic Architecture for DEL-1 Well}

The interplay between the observed distribution patterns of Discoaster species, Helicosphaera species and Reticulofenestra coccolith sizes within the studied succession allow some insightful deductions to infer possible palaeoceanographic architecture for the studied well. Evident during the period of $17 \mathrm{Ma}$ - older (8500-9450 ft), a steady increase in abundance of lower photic zone species of Discoaster (Figures 4 and 6) and dominant abundance of large Reticulofenestra coccoliths (Figure 7) show the development 
of thermocline and nutricline largely supported by stable ocean water condition, low nutrient content and sun penetration (Gallagher, 1989; Hagino et al., 2000; Herrmann \& Thierstein, 2012). Conceivably, it suggests the dominance of oligotrophic oceanographic conditions that influenced the productivity and enhanced size of the Reticulofenestra coccoliths. These scenarios are similar to the palaeoceanographic situation described in the western Equatorial Pacific Ocean within NN2-NN5 Zone (Farida et al., 2012) and the NN6-NN8 Zone in the Indian Ocean of DSDP sites (Young, 1990) with a slight difference in the timing of NN4 in this study.

A critical look into horizons within depth interval 7500-8000 ft shows sparse to the low occurrence of nannoliths with Helicosphaera carteri and Calcidiscus leptoporus standing as a resistant species in their abundances. The bioevents above 17.4 Ma horizons suggest step by step collapse of the thermocline and nutricline that signifies possible dominance of mesotrophic oceanographic condition, which often results in complex nannofloral patterns (Haq, 1980; Young, 1994; Imai et al., 2015). This scenario could be presented as a transitional condition responsible for the observed continuous fluctuating NAR, the relative abundances of Discoaster species and the relative abundance of small Reticulofenestra species in this study. Moreover, nannofloral diversity and abundance are often favoured by mesotrophic and stable water environments, and by implication, characterize the surface water productivity within the low to middle latitude oceans (Young, 1994; Erba, 2006). Furthermore, these oceanic waters are known for their warm temperature that typifies the Miocene climatic condition (Haq \& Lohmann, 1976; Haq, 1980, Imai et al., 2015).

Small Reticulofenstra and Sphenolithus species are regarded as indicators of eutrophic conditions while typically found in upwelling related areas (Flores et al., 1995; Kameo, 2002; Imai et al., 2015). The bioevents surrounding 15.9 Ma in this study are generally characterized by low and persistent environmental resistance species within intervals 6490-7780 ft. It suggests the interval continuously experience mesotrophic conditions sequel to potential changes at the sea surface. However, the dominant occurrence of small Reticulofenstra species and the modal sizes could trigger the overriding effect of eutrophication (Flores et al., 1995; Kameo, 2002). Therefore, the depth interval 4500-6490 $\mathrm{ft}$ is regarded as strong eutrophication with the abundant occurrence of small Reticulofenstra and gradual decrease in nannofloral abundance and diversity up-hole to characterize the ecostratigraphic events and the bioevents recorded around 15.0 Ma. However, this attests to various emphases placed on small size Reticulofenstra species to determine the influence of eutrophication on Miocene palaeoceanographic conditions (Young, 1994; Erba, 2006; Herrmann \& Thierstein, 2012; Imai et al., 2015).

LaRiviere et al. (2012) proposed that a continuous relative shoaling of thermocline and reduction in low-latitude gradients in sea surface temperature supports appreciable nutrients could have induced the establishment of eutrophic conditions experienced within depth interval $(5000-6490 \mathrm{ft})$. It could have been initiated probably from the low to moderate 
abundance and diversity of calcareous nannofossils in mesotrophic habitats that precede the interval. The influence of these factors mentioned above perhaps enlightens the coupling between $\mathrm{pCO}_{2}$, sea surface temperatures, and climatic conditions on the warmth of the Miocene age (Bown et al. 2004). Imai et al. (2015) pointed that strong eutrophication is supported by coastal upwelling or nutrient-rich terrestrial events. Thus, it could be inferred that the fluvial mechanism responsible for the deposition of the encroached Opuama Canyon's (Ozumba, 2018) could enhance the influx of nutrient-rich terrestrial sediments (see deposited sand units in Figure 3) into the western DFZ within the Gulf of Guinea to support the eutrophication of the surface water.

Moreover, this study highlights a decrease in abundance of less-resistant calcareous nannofossils and an overall decrease in species richness within depth interval 4600-8000 $\mathrm{ft}$ (Figure 4). Thus, suggest the presence of carbonate crash in reference to its occurrence in another related low to middle latitude oceans (Fadiya \& Salami, 2012; Honisch et al., 2012). In this study, this phenomenon is marked within the upper section of NN4 and lower section of NN5 of the studied Miocene succession. In other words, it could be interpreted that the phenomenon is likely ascribed with dissolution or low carbonate productivity effects, coupled with the developmental changes from mesotrophic to eutrophic conditions of the sea surface during the early to middle Miocene experienced in this local area. Moreover, it is widely known that the dissolution of coccoliths is not species-selective; therefore, nannofossils are sensitive indicators to a degree of dissolution and perhaps environmental changes (Boyce et al., 2010; Honisch et al., 2012). Consequently, decrease in abundance of fewer dissolution-susceptible taxa, cyclic decrease in the abundance of Discoaster species, and relative abundance of resistant species of Calcidiscus leptoporus, Helicosphaera carteri and Sphenolithus species were highlighted in this study. Thus, suggest the strong influence of carbonate dissolution effect than low surface water productivity on the induced warm waters dominant in the study area (Lyle et al., 1995; Honisch et al., 2012).

\section{Comparative View with Other Oceans}

In this study, the disappearance of Oligocene type species with the replacement of Discoaster-Sphenolithus-Reticulofenestra assemblages in the early to middle Miocene (Figure 4) could signal gradual dominance of warm water of induced-climatic events (Haq \& Lohmann, 1976; Haq, 1980). It is supported by gradual displacement of large size Reticulofenestra species with the dominant presence of small size species in the middle Miocene, similar to the nannoflora event reported in the north-western Pacific and eastern Indian Ocean (Imai et al., 2015). Moreover, this study highlights the dominance of distinct medium to large size Reticulofenestra coccoliths with the fluctuating occurrence of Discoaster spp., to characterise the early Miocene succession (Figure 4). This scenario suggests the initial gradual collapse of the thermocline at a period when ocean chemistry 
and salinity become unstable as a result of terrestrial influxes and possible carbon dissolution (Jiang et al., 2007; Fadiya \& Salami, 2012). Perhaps influence the distribution and biodiversity of the associated calcareous nannoplanktons used by Pujos $(1985,1987)$ to decipher the thermal structure of water masses from the Central Pacific DSDP site within the mid-latitude.

The general observed up-hole changes in Reticulofenestra coccoliths size and bimodalisation during the middle Miocene register a trend in this study (Figure 6). This ascribed phenomenon is regarded as a taxonomic marker responsible for ideal variations in nannoliths niches in palaeo-oceans (Backman, 1984; Young, 1994; Farinaciari et al., 2000; Herrmann \& Thierstein, 2012). The size variation patterns have been summarized with two extreme possibilities; first, they represent the effect of ecological factors on genetically unchanging populations. Second, that they show evolutionary change without environmental change, the limitation of this study could not allow a distinct definition between the two facts. However, from our observation, since the size range and modal size vary independently, and cyclic dominance of ecologic species like Discoaster-SphenolithusReticulofenestra-Calcidiscus-Coccolithus assemblages, thus, suggest the phenomenon would not be as a result of a single external factor, i.e., temperature. Rather, we suggest a combined effect of both evolutionary events of genotypic variation (Bown et al., 2004; Erba, 2004; Erba et al., 2004) and ecological control (Farida et al., 2012; Fadiya \& Salami, 2012) might be responsible for the size variation. Seemingly, this phenomenon has been reported in the Atlantic Ocean DSDP site 116 within NN3-NN10 (Haq, 1980), similarly recorded in the western equatorial Pacific Ocean within 5.0-6.0 Ma (Farida et al., 2012), the Indian Ocean at 6.0 Ma (Young, 1990), and north-western Pacific and the eastern Indian Ocean within 6.4-5.0 Ma (Imai et al., 2015).

Some articles on the premise of Reticulofenestra size variation and ecological modifications exhibited by Discoaster-Sphenolithus-Calcidiscus assemblages in middle Miocene sediments across the oceans mentioned above, are construed to be a widespread low to the middle-latitude event (Young, 1990; Farida et al., 2012; Imai et al., 2015). However, this suggests the oceans might have possibly shared a similar interplay between environmental factors $\left(\mathrm{CCO}_{2}, \mathrm{pH}\right.$, temperature, salinity, light, oxygen, and nutrient levels) and evolutionary control to reflect on the overarching pattern of nannofloras as a result of changes/variability in stability of the sea surface conditions (Young, 1990; Erba, 2006). Conversely, this study noted the presence of bimodality and an abrupt reduction of Reticulofenestra coccolith modal size to coincide with an increase in NAR and decrease in Discoaster species abundance, which is similar to the nannoflora pattern in the northwestern Pacific and the eastern Indian Ocean within 6.4-5.0 Ma (Imai et al., 2015). Though at different timing, thus, suggests a marine event induced by latitudinal climatic changes that resulted in changes in environmental conditions of the surface waters (Young, 1990; Holcová, 2005; Farida et al., 2012, Imai et al., 2015). 


\section{CONCLUSIONS}

The studied well has been examined of its palaeoecologic and palaeoceanographic conditions inferred from the recouped calcareous nannofossil assemblages. The biostratigraphic analysis reveals low to moderate abundance and moderate diversity of calcareous nannofossils that enabled the recognition of nannofossil zones NN4 and NN5, which span early to middle Miocene age. The palaeoenvironment is interpreted to range between intertidal to tidal sub-facies to shelf mud deposition in neritic settings. The variances in the relationship among the ecologic proxies suggest that the early Miocene's lower horizons are characterised by deep thermocline and nutricline, a typical representative of dominant oligotrophic conditions.

A short mesotrophic condition, generally characterized with sparse to the low occurrence of nannoliths, aside from the abundance of resistant Helicosphaera species in the upper interval of early Miocene, suggests the initial collapse of the thermocline and nutricline of the sea surface water. Consequently, gradual but notably low abundance of dissolution-susceptible taxa within the middle Miocene horizons implies the presence of carbonate crashes like other worlds' oceans. Thus, suggest strong eutrophication with the potential collapse of the surface waters, coupled with the influx of nutrient-rich terrestrial sediments resulting from the prevailed induced-climatic events in the middle Miocene horizons within the Gulf of Guinea axis of the Atlantic Ocean.

The recouped calcareous nannofossil assemblages show a gradual stepwise reduction in nannofossil distribution from early to middle Miocene, thus, suggest a local collapse of the sea surface stratification in the oceanic water around the study area. Moreover, the suggested changes from dominant oligotrophic to short mesotrophic conditions in the early Miocene, finally to a eutrophic condition in the middle Miocene. Thus, construe the oceanic water and the environmental properties of the sea surface water to have engaged in dynamic changes similar to situations in low latitude regions like the Indian Ocean, Caribbean, southern South America, eastern equatorial Pacific and the western coast of Central Africa. However, the timing of the inferred eutrophication in the Gulf of Guinea might slightly differ from other world oceans, suggesting marine events induced by the latitudinal climatic change that influence changes in environmental conditions of the surface waters.

\section{ACKNOWLEDGEMENT}

My sincere appreciation goes to the Geologic Service Unit (SNEPCO) for the provision of ditch cutting samples used for this research. Also, I appreciated Prof. Dr. Che Aziz Ali for his constructive criticism on the research that led to this manuscript. I sincerely appreciate the role played by Dr. Adepehin to suggest different articles to support my findings on the geology of Niger Delta. 


\section{REFERENCES}

Adegoke, O. S., Oyebamiji, A. S., Edet, J. J., Osterloff, P. L., \& Ulu, O.K. (2017). Cenozoic foraminifera and calcareous nannofossil biostratigraphy of the Niger Delta. Elsevier Incorporation. http://dx.doi. org/10.1016/C2016-0-03240-0

Ajayi, E. O., \& Okosun, E. A. (2014). Calcareous nannofossil biostratigraphy of A, B, C, D wells, offshore Niger Delta, Nigeria. Earth Science Research, 3(1), 108-123. http://doi:10.5539/esr.v3n1p108

Aubry, M. P. (1992). Late Paleogene calcareous nannoplankton evolution: A tale of climatic deterioration. In D. R. Prothero, \& W. A. Berggren (Eds.), Eocene-Oligocene Climatic and Biotic Evolution (pp. 272-309). Princeton University Press. https://doi.org/10.1515/9781400862924.272

Backman, J. (1984). Cenozoic calcareous nannofossils and biostratigraphy from the North Eastern atlantic ocean-deep sea drilling project leg 81. In D. G. Roberts, \& D. Schnittker (Eds.), Initials reports of the deep sea drilling project (Vol. 81, pp. 403-428). Washington U.S. Govt. Office. http://doi.org/10.2973/ dsdp.proc.81.105.1984

Bilotti, F., \& Shaw, J. H. (2005). Deep-water Niger Delta fold and thrust belt modelled as a critical-taper wedge: The influence of elevated basal fluid pressure on structural styles. Association American Petroleum Geologists Bulletin, 89(11), 1475-1491. https://doi.org/10.1306/06130505002

Bilotti, F., Shaw, J. H, Cupich, R. M., \& Lakings, R. M. (2005). Detachment fold, Niger Delta. In J. H. Shaw, C. Connors, \& J. Suppe, (Eds.), Seismic interpretation of contractional fault related folds (Vol. 53, pp. 103-104). Association American Petroleum Geologists.

Bown, P. R. (1999). Calcareous nannofossil biostratigraphy. Kluwer Academic Publication. https://doi. org/10.1007/978-94-011-4902-0

Bown, P. R., \& Dunkley, J. T. (2012). Calcareous nannofossils from the Paleogene equatorial Pacific (IODP Expedition 320 Sites U1331-1334). Journal of Nannoplankton Research, 32(2), 3-51.

Bown, P. R., \& Young, J. R. (1998). Techniques. In P. R. Bown (Ed.), Calcareous nannofossil biostratigraphy (pp. 16-26). Kluwer Academic Publication. https://doi.org/10.1007/978-94-011-4902-0_2

Bown, P. R., Lees, J. A., \& Young, J. R. (2004). Calcareous nannoplankton evolution and diversity through time. In H. R. Thierstein, \& J. R. Young (Eds.), Coccolithophores - From molecular processes to global impact (pp. 481-508). Springer. https://doi.org/10.1007/978-3-662-06278-4_18

Boyce, D., Lewis, M., \& Worm, B. (2010). Global phytoplankton decline over the past century. Nature, 466, 591- 596. http://doi:10.1038/nature09268

Bramlette, M. N., \& Wilcoxon, J. A. (1967). Middle tertiary calcareous nannoplankton of the Cipero section, Trinidad, W.I. Tulane Studies in Geology and Paleontology, 5, 93-131.

Brown P. R. (2005). Paleogene calcareous nannofossils from the Kilwa and Lindi areas of coastal Tanzania (Tanzania Drilling Project 2003-4). Journal of Nannoplankton Research, 27, 21-95.

Bukry, D., \& Bramlette, M. N. (1969). Some new and stratigraphically useful calcareous nannofossils of the Cenozoic. Tulane Studies in Geology, 7, 131-142. 
Connors, C. D., Denson, D. B., Kristiansen, G., \& Angstadt, D. M. (1998). Compressive anticlines of the mid-outer slope, central Niger Delta (abs.). Association American Petroleum Geologists Bulletin, 82(10), Article 1903.

Corredor, F., Shaw, J. H., \& Bilotti, F. (2005). Structural styles in the deepwater fold-and-thrust belts of the Niger Delta. Association American Petroleum Geologists Bulletin, 89(6), 753-780. https://doi. org/10.1306/02170504074

Doust, H., \& Omatsola, E. (1990). Niger delta. In J. D. Edwards \& P. A. Santogrossi (Eds.), Divergent/passive margin basins (pp. 201-238). American Association of Petroleum Geologists Memoir.

Erba, E. (2004). Nannofossils and Mesozoic oceanic anoxic events. Marine Micropaleontology, 52, 85-106. https://doi.org/10.1016/j.marmicro.2004.04.007

Erba, E. (2006). The first 150 million years history of calcareous nannoplankton: Biosphere-geosphere interactions. Palaeogeography, Palaeoclimatology, Palaeoecology, 232, 237-250. https://doi.org/10.1016/j. palaeo.2005.09.013

Erba, E., Bartolini, A., \& Larson, R. L. (2004). Valanginian Weissert oceanic anoxic event. Geology, 32(2), 149-152. https://doi.org/10.1130/G20008.1

Fadiya, S. L. (1999). Foraminifera and calcareous nannofossils biostratigraphy and well-log sequence Stratigraphic analysis of Opolo-5 and Opolo-6 wells, Niger Delta. (Unpublished Master Thesis). Obafemi Awolowo University, Nigeria.

Fadiya, S. L., \& Salami, M. B. (2012). Middle Miocene carbonate crash in the Niger Delta: Evidence from calcareous nannofossils. Journal of Nannoplankton Research, 32(2), 59-70.

Farida, M., Imai, R., \& Sato, T. (2012). Miocene to Pliocene Paleoceanography of the western equatorial Pacific Ocean based on Calcareous nannofossils, ODP Hole 805B. Open Journal Geology, 2, 72-79. https://doi. org/10.4236/ojg.2012.22008

Farinaciari, E. S., Rio, A. D., \& Negri, A. (2000). Middle Miocene quantitative calcareous nannofossils biostratigraphy in the Mediterranean region. Journal of Micropalaeontology, 42, 38-64.

Flores, J. A., \& Sierro, F. J. (1987). Calcareous plankton in the Tortonian/Messinian transition series of the Northwestern edge of the Guadalquivir Basin. Abhandlungen der Geologischen Bundesanstalt, 39, 67-84.

Flores, J. A., \& Sierro, F. J. (1997). Revised technique for calculation of calcareous nannofossil accumulation rates. Marine Micropaleontology, 43, 321-324. https://doi.org/10.2307/1485832

Flores, J. A., Sierro, F. J., \& Raffi, I. (1995). Evolution of the calcareous nannofossil assemblage as a response to the Palaeoceanographic changes in the eastern equatorial Pacific Ocean from 4 to 2 Ma, Leg 138, sites 849 and 852. In N. G. Pisias, L. A. Mayer, T. R. Janecek, A. Palmer-Julson, \& T. H. van Andel, T. H. (Eds.), Proceedings of the Ocean Drilling Program, Scientific Results (Vol. 138, 163-176). Ocean Drilling Program College Station. https://doi.org/10.2973/odp.proc.sr.138.109.1995

Flores, J. A., Sierro, F. J., Filippelli, G. M., Bárcena, M. Á., Pérez-Folgado, M., Vázquez, A., \& Utrilla, R. (2005). Surface water dynamics and phytoplankton communities during deposition of cyclic late Messinian sapropel sequences in the western Mediterranean. Marine Micropaleontology, 56, 50-79. https://doi. org/10.1016/j.marmicro.2005.04.002 
Gallagher, L. (1989). Reticulofenestra: A critical review of taxonomy, structure and evolution. In J. A. Crux, \& S. E. van Heck (Eds.), Nannofossils and their applications (pp. 41-75). Ellis Horwood Ltd.

Gartner, S. (1992). Miocene nannofossil chronology in the north Atlantic, DSDP Site 608. Marine Micropaleontology, 18, 307-331. https://doi.org/10.1016/0377-8398(92)90045-L

Gradstein, F. M., Ogg, J. G., Schmitz, M. D., \& Ogg, G. M. (2020). A geologic time scale. Elsevier. https:// doi.org/10.1016/B978-0-12-824360-2-00001-2

Guerra, R. D., Tokutake, L., \& Fauth, G. (2011). Cretaceous calcareous nannofossils from Pelotas Basin, Brazil: Biostratigraphic and paleoecological inferences. Journal of South American Earth Sciences, 36, 55-71. https://doi.org/10.016/j.jsames.2011.10.008

Hagino, K., Okada, H., \& Matsuoka, H. (2000). Spatial dynamics of coccolithophore assemblages in the equatorial Western-Central Pacific Ocean. Marine Micropaleontology, 39, 53-72. https://doi.org/10.1016/ S0377-8398(00)00014-1

Haq, B. U. (1966). Electron microscope studies on some upper Eocene calcareous nannoplankton from Syria. Stockholm Contributions in Geology, 15, 23-37.

Haq, B. U. (1980). Biogeographic history of Miocene calcareous nannoplankton and paleoceanography of the Atlantic Ocean. Marine Micropaleontology, 26(4), 414-443. https://doi.org/10.2307/1485353

Haq, B. U., \& Lohmann, G. P. (1976). Early Cenozoic calcareous nannoplankton biogeography of the Atlantic Ocean. Marine Micropaleontology, 1, 111-194. https://doi.org/10.1016/0377-8398(76)90008-6

Haq, B. U., Hardenbol, J., \& Vail, P. R. (1988). Mesozoic and Cenezoic chrostratigraphy and eustatic cycles. In C. K. Wilgus, B. S. Hastings, C. G. S. C. Kendall, H. W. Posamentier, C. A. Ross, \& J. C. Van Wagnoner (Eds.), Sea-level changes: An integrated approach (Vol. 42, pp. 71-108). SEPM Special Publication. https://doi.org/10.2110/pec.88.01.0071

Hay, W. W., Mohler, H. P., Roth, P. H., Schmidt, R. R., \& Boudreaux, J. E. (1967). Calcareous nannofossils from Nal'chik (northwest Caucasus). Eclogae Geologicae Heloetiae, 59, 379-399.

Herrmann, S., \& Thierstein, H. R. (2012). Cenozoic coccolith size changes - Evolutionary and/or ecological controls. Palaeogeography Palaeoclimatology Palaeoecology, 333, 92-106. https://doi.org/10.1016/j. palaeo.2012.03.011

Holcová, K. (2005). Quantitative calcareous nannoplankton biostratigraphy of the Oligocene/Miocene boundary interval in the northern part of the Buda Basin (Central Paratethys). Geological Quarterly, 49, 263-274.

Honisch, B., Ridgwell, A., Schmidt, D. N., \& Thomas, E. (2012). The geological recorded of ocean acidification. Science, 335(6072), 1058-1063. https://doi.org/10.1126/science.1208277

Imai, R., Farida, M., Sato, T., \& Iryu, Y. (2015). Evidence for eutrophication in the northwestern Pacific and eastern Indian oceans during the Miocene to Pleistocene based on the nannofossil accumulation rate, Discoaster abundance, and coccolith size distribution to Reticulofenestra. Marine Micropaleontology, 116, 15-27. http://dx.doi.org/10.1016/j. marmicro.2015.01.001.

Jiang, S., Jr Wise, S. W., \& Wang, Y. (2007). Cause of the middle/late miocene carbonate crash: Dissolution or low productivity? In D. A. H. Teagle, D. S. Wilson, G. D. Acton, \& D. A. Vanko (Eds.), Proceedings 
of the Ocean Drilling Program, Scientific Results (Vol. 206, pp. 1-24). Ocean Drilling Program College Station. https://doi.org/10.2973/odp.proc.sr.206.013.2007

Kamptner, E. (1954) Untersuchungen über den feinbau der coccolithen anzeiger [Investigations into the fine structure of the coccoliths. indicator]. Österreichische Akademie der Wissenschaften. MathematischeNaturwissenchaftliche Klasse, 87, 152-158.

Kameo, K. (2002). Late Pliocene Caribbean surface water dynamics and climatic changes based on calcareous nannofossil records. Palaeogeography, Palaeoclimatology, Palaeoecology, 179, 211-226. https://doi. org/10.1016/S0031-0182(01)00432-1

Kameo, K., Shindo, R., \& Takayama, T. (2010). Calcareous nannofossil biostratigraphy and geologic age of the Kiyosumi Formation of the Awa Group, Boso Peninsula, central Japan: Age determination based on size variations of Reticulofenestra specimens (in Japanese with English abstract). Journal Geology Society of Japan, 116, 563-574. https://doi.org/10.5575/geosoc.116.563

LaRiviere, J. P., Ravelo, A. C., Crimmins, A., Dekens, P. S., Ford, H. L., \& Lyle, M. (2012). Late Miocene decoupling of oceanic warmth and atmospheric carbon dioxide forcing. Nature, 486, 97-100. https://doi. org/10.1038/nature11200

Loeblich, A. R., \& Tappan, H. (1978) The coccolithophorid genus Calcidiscus Kamptner and its synomyms. Journal of Paleontology, 52, 1390-1392.

Lyle, M., Dadey, K. A., \& Farrel, J. W. (1995). The Late Miocene (11-8Ma) eastern Pacific carbonate crash: Evidence of reorganization of deepwater circulation by the closure of the Panama Gateway. In N. G. Pisias, L. A. Mayer, T. R. Janecek, A. Palmer-Julson, \& T. H. van Andel (Eds.), Proceedings of the Ocean Drilling Program, Scientific Results (Vol. 138, pp. 821-838). Ocean Drilling Program College Station. https://doi.org/10.2973/odp.proc.sr.138.157.1995

Magbagbeoloa, O., \& Willis, B. J. (2007). Sequence stratigraphy and syndepositional deformation of the Agbada Formation, Robertkiri field, Niger Delta, Nigeria. American Association of Petroleum Geologists Bulletin, 91, 945-958. https://doi: 10.1306/02050705150.

Martini, E. (1965). Mid-Tertiary calcareous nannoplankton from Pacific deep-sea cores. Colston Papers, 17, 393-411.

Martini, E. (1971). Standard tertiary and quaternary calcareous nannoplankton zonation. In A. Farinacci (Ed.), Proceedings of the Second Planktonic Conference (Vol. 2, pp. 739-765). CiNii Publication.

McIntyre, A., \& Bé, A. H. (1967). Modern coccolithophoridae of the Atlantic ocean - I. Placoliths and cyrtoliths. Deep-Sea Research, 14, 561-597. https://doi.org/10.1016/0011-7471(67)90065-4

Momta, P. S., \& Odigi, M. I. (2014, November 9-13). Sequence stratigraphic framework and depositional architecture of MP field, shallow offshore, Niger Delta, Nigeria. In Proceedings of the NAPE Annual International Conference and Exhibitions (pp. 9-13). Lagos, Nigeria.

Müller, C. (1981). Beschreibung neuer Helicosphaera-Arten aus dem Miozän und Revision biostratigraphischer Reichweiten einiger neogener Nannoplankton-Arten [Description of new Helicosphaera species from the Miocene and revision of the biostratigraphic ranges of some neogenic nannoplankton species]. Senckenbergiana Lethaea, 61, 427-435. 
Murray, G., \& Blackman, V. H. (1898). On the nature of the coccospheres and rhabdospheres. Philosophical Transactions of the Royal Society, 190, 27-411. https://doi.org/10.1098/rstb.1898.0006

Obaje, S. O., \& Okosun, E. A. (2013). Taxonomic notes on Coccolithophorids from Tomboy Field, offshore western Niger Delta, Nigeria. International Journal of Science and Technology, 2(11), 814-821.

Ojo, E. A., Fadiya, L. S., \& Ehinola, O. A. (2009). Biozonation and correlation of BDX-1 and BDX-2 wells of deep offshore Niger Delta using calcareous nannofossils. In American Association of Petroleum Geologists (pp. 8-21). Search and Discovery Article.

Ola, P. (2018). Morphological description of calcareous nannofossils assemblage of a middle-miocene to latemiocene section in the Niger-Delta, Nigeria. Open Journal of Geology, 8, 925-936. http://doi:10.4236/ ojg.2018.89055.

Oyebamiji, S. A. (1997). Calcareous nannofossils biostratigraphy of a well in the Niger Delta, Nigeria (Unpublished Master Thesis). University College, London.

Ozumba, B. M. (2018). Stratigraphic framework of the Western Central Swamp of the Niger Delta, Nigeria. Scientific Environment, 1, 105-114.

Perch-Nielsen, K. (1985). Cenozoic calcareous nannofossils. In H. M. Bolli, J. B. Saunders, \& K. Perch-Nielsen (Eds.), Plankton stratigraphy (pp. 427-554). Cambridge University Press.

Perch-Nielsen, K. (1989). Mesozoic and Cenozoic calcareous nannofossils. In H. M. Bolli, J. B. Saunders, \& K. Perch-Nielsen (Eds.), Plankton stratigraphy (pp. 329-554). Cambridge University Press.

Pujos, A. (1985). Cenozoic nannofossils, Central Equatorial Pacific. Initial Report Deep Sea Drilling Project Leg 85 (IRDSDP), 15, 581-607. http://doi:10.2973/dsdp.proc.85.114.1985.

Pujos, A., (1987). Late Eocene to Pleistocene medium-sized and small-sized "reticulofenestrids". Abhandlungen der Geologischen Bundesanstalt, 39, 239-277.

Raffi, I., Backman, J., Fornaciari, E., Palike, H., Rio, D., Lourens, L., \& Hilgen, F., (2006). A review of calcareous nannofossil astrobiochronology encompassing the past 25 million years. Quaternary Scientific Review, 25(23), 3113-3137. https://doi.org/10.1016/j.quascirev.2006.07.007

Reijers, T. J. A. (2011). Stratigraphy and sedimentology of the Niger Delta. Geologos, The Netherlands, 17(3), 133-162. https://doi.org/10.2478/v10118-011-0008-3

Roth, P. H. (1970). Oligocene calcareous nannoplankton biostratigraphy. Eclogae Geologicae Helvetiae, 63, $799-881$.

Sanuade, O. (2014). Calcareous nannofossil biostratigraphic analysis of well 'K-2', deep offshore Niger Delta, Nigeria. Advances in Research, 2, 696-711. http://doi:10.9734/AIR/2014/11364.

Sato, T., \& Chiyonobu, S. (2009). Cenozoic paleoceanography indicated by size change of calcareous nannofossil and discoaster number (in Japanese with English abstract). Fossils (Palaeontological Society of Japan), 86, 12-19.

Schiller, J. (1930). Coccolithineae. In L. Rabenhorst (Ed.), Kryptogamen-Flora (pp. 89-273). Akademische Verlagsgesellschaft. 
Selley, R. C. (1985). Ancient Sedimentary Environments. Cornell University Press. https://doi.org/10.1002/ gea.3340020207

Vulc, A., \& Silye, L. (2005). Preliminary data on biostratigraphy and paleoecology of calcareous nannofossils and foraminifera in Cepari Quarry (North-Eastern Transylvania, Romania). Acta Palaentological Romanie, $5,493-501$.

Wallich, G. C. (1877). Observations on the coccosphere. Annals and Magazine of Natural History, 19, 342350. https://doi.org/10.1080/00222937708682153

Young, J. R. (1990). Size variation of Neogene Reticulofenestra coccoliths from Indian Ocean DSDP cores. Journal of Micropalaeontology, 9, 71-86. http://doi:10.1144/jm.9.1.71

Young, J. R. (1994). Functions of coccoliths. In A. Winter, \& W. G. Siesser (Eds.), Coccolithophores (pp. 63-82). Cambridge University Press.

Young, J. R. (1998). Neogene. In P. Bown (Ed.), Calcareous nannofossil biostratigraphy, (pp. 225-265). British Micropaleontology Society Publication. https://doi.org/10.1007/978-94-011-4902-0_8

Zachos, J. C., Kroon, D., \& Blum, P. (2004). Early Cenozoic extreme climates: The walvis ridge transect. Oceanographic Institutions Inc.

Zervas, D., Nichols, G., Hall, R., Smyth, H., Luthje, C., \& Murtagh, F. (2009). SedLog: A shareware program for drawing graphic logs and log data manipulation. Computers and Geosciences, 35(10), 2151-2159. https://doi.org/10.1016/j.cageo.2009.02.009.

Zhang, J., Wang, P., Li, Q., Cheng, X., Jin, H., \& Zhang, S. (2007). Western equatorial pacific productivity and carbonate dissolution over the last $150 \mathrm{kyr}$ : Foraminiferal and nannofossil evidence from ODP Hole 807A. Marine Micropaleontology, 64(3-4), 121-140. https://doi.org/10.1016/j.marmicro.2007.03.003 